\title{
PERAN KANTOR WILAYAH PROVINSI JAMBI DALAM PENYELESAIAN SENGKETA PERTANAHAN MELALUI MEKANISME MEDIASI
}

\author{
Sigit Somadiyono ${ }^{1}$ \\ Dosen Fakultas Hukum Universitas Batanghari Jambi \\ sigit_321@yahoo.com
}

\begin{abstract}
Abstrak
Mediasi adalah salah satu cara untuk menyelesaikan permasalahan secara non litigasi, dimana para pihak duduk bersama dengan difasilitasi oleh mediator yang dalam penelitian ini dilakukan oleh Kantor Wilayah BPN Provinsi Jambi. Permasalahan yang diangkat dalam penelitian ini adalah bagaimana jenis sengketa pertanahan yang diselesaikan melalui jalur mediasi di Kantor Wilayah Badan Pertanahan Nasional Provinsi Jambi dan bagaimana peran Kantor Wilayah Badan Pertanahan Nasional Provinsi Jambi dalam penyelesaian sengketa pertanahan melalui mekanisme mediasi. Tujuan dari penelitian ini adalah untuk mengetahui jenis perkara apa saja yang dimintakan mediasi kepada Kantor Wilayah BPN Provinsi Jambi serta peran Kantor Wilayah BPN Provinsi Jambi dalam proses mediasi.
\end{abstract}

Kata Kunci : Peran, Mediasi, BPN.

\begin{abstract}
Mediation is one of the ways to resolve the issue of non litigation, where the parties sit together facilitated by the mediator which is in this study was conducted by Regional Office of National Land Agency of Jambi Province. The issue appointed by this research is how is the type of line dispute settled through the mediation path in Regional Office of National Land Agency of Jambi Province and how is the role of Regional Office of National Land Agency of Jambi Province in the settlement of land disputes through mediation mechanisms. The purpose of this research is to find out what type of case that is requested by mediaton to Regional Office of National Land Agency of Jambi Province and the role of Regional Office of National Land Agency of Jambi Province in process of the mediation.
\end{abstract}

Keywords: content, formatting, article

\section{PENDAHULUAN}

Hubungan tanah dengan manusia tidak hanya sekedar tempat hidup, tetapi lebih dari itu tanah memberikan sumber daya bagi kelangsungan hidup umat manusia. Begitu pentingnya kedudukan tanah bagi manusia tidak jarang menyebabkan terjadinya sengketa tentang tanah. Sengketa akhir-akhir ini semakin komplek. Pemicunya tidak sebatas aspek ekonomi saja, melainkan sosial dan budaya bahkan juga agama. Menurut Rusmadi Usman (1991:22), Timbulnya sengketa hukum mengenai tanah berawal dari pengaduan suatu pihak (orang atau badan hukum) yang berisi keberatan-keberatan dengan harapan dapat memperoleh penyelesaian secara administrasi sesuai dengan ketentuan peraturan yang berlaku.

\footnotetext{
${ }^{1}$ Dosen Fakultas Hukum Universitas Batanghari Jambi
} 
Penyelesaian sengketa dapat dilakukan melalu 2 (dua) cara. Cara penyelesaian sengketa pertama melalui proses litigasi di dalam pengadilan, kemudian berkembang proses penelesaian sengketa melalui kerjasama (kooperatif) di luar pengadilan yang biasa disebut proses non litigasi. Rachmadi Usman (2003:3) mengatakan bahwa proses litigasi menghasilkan putusan yang bersifat pertentangan (adversarial) yang belum mampu merangkul kepentingan bersama, bahkan cenderung menimbulkan masalah baru, lambat dalam penyelesaiannya, membutuhkan biaya yang mahal, tidak responsif, dan menimbulkan permusuhan diantara pihak yang bersengketa.

Penyelesaian non litigasi mempunyai beberapa bentuk untuk menyelesaikan sengketa yaitu Negosiasi, Mediasi dan Arbitrase. Ketiga bentuk penyelesaian sengketa tersebut dilakukan oleh pihak yang merasa dirugikan atau terjadinya perbedaan pendapat baik itu antara individu, kelompok maupun antar badan usaha. Penyelesaian sengketa non litigasi dilakukan untuk menyelesaikan sengketa dengan cara musyawarah mufakat dan hasil penyelesaian konflik atau sengketa secara kekeluargaan.

Sengketa hukum atas tanah tidak dapat dilepaskan kaitannya dengan Negara Kesatuan Republik Indonesia yaitu negara yang berorientasi kepada kesejahteraan umum sebagaimana tersurat dalam Undang-Undang Dasar Republik Indonesia 1945. Menurut Pasal 1 angka 1 Peraturan Menteri Agraria dan Tata Ruang/Kepala Badan Pertanahan Nasional Republik Indonesia Nomor 11 Tahun 2016 tentang Penyelesain Kasus Pertanahan (selanjutna disebut Permen ATR/BPN No. 11/2016), kasus pertanahan adalah Sengketa, Konflik, atau Perkara Pertanahan untuk mendapat penanganan penyelesaian sesuai dengan ketentuan peraturan perundangundangan/kebijakan pertanahan. Pasal 1 angka 2 Permen ATR/BPN No. 11/2016 menyebutkan sengketa tanah adalah perselisihan pertanahan antara orang perseorangan, badan hukum atau lembaga yang tidak berdampak luas.

Faktor penyebab timbulnya sengketa atau konflik pertanahan adalah:

1. Perbandingan luas tanah dan pertumbuhan penduduk tidak seimbang;

2. Tanah sudah menjadi komoditi ekonomi;

3. Ketimpangan struktur penguasaan tanah;

4. Tumpang tindih peraturan dan lembaga yang menangani pertanahan;

5. Penelantaran tanah

6. Tidak tertib administrasi pengelolaan aset tanah.

Dalam Pasal 16 Undang-Undang Nomor 5 Tahun 1960 tentang Peraturan Dasar Pokok-Pokok Agraria (UUPA) diatur tentang hak-hak atas tanah yang dapat diberikan kepada warganegaranya berupa yang paling utama adalah Hak Milik, Hak Guna Usaha, Hak Guna Bangunan, Hak Pakai, Hak Sewa, Hak Membuka Tanah, Hak untuk Memungut Hasil Hutan dan hak-hak lain yang tidak termasuk dalam hak-hak tersebut di atas akan ditetapkan dengan undang-undang serta hak-hak yang sifatnya sementara sebagaimana disebutkan dalam Pasal 53 UUPA.

Salah satu lembaga pemerintahan di Indonesia yang mempunyai hubungan erat dengan pertanahan adalah Badan Pertanahan Nasional yang disingkat BPN yang diatur oleh Peraturan Pemerintah (PP) No. 10 Tahun 2006 tentang Badan Pertanahan Nasional. Secara garis besar menurut Pasal 1 PP No. 10 Tahun 2006, BPN adalah Lembaga Pemerintah Non Departemen yang berada di bawah dan bertanggung jawab 
kepada Presiden. Selanjutnya pada Pasal 2 nya menyatakan bahwa BPN mempunyai tugas melaksanakan tugas pemerintah di bidang pertanahan secara nasional, regional dan sektoral. Dengan adanya ketentuan peraturan pemerintah ini, maka secara jelas BPN mempunyai tugas dan tanggungjawab di bidang pertanahan secara nasional atau daerah.

Salah satu bidang kerja BPN di daerah adalah Kantor Wilayah BPN Provinsi Jambi. Kantor Wilayah Badan Pertanahan Nasional Provinsi Jambi adalah instansi vertikal BPN yang ada di Provinsi Jambi yang berada di bawah pertanggungjawaban langsung kepada Menteri dan mensupervisi Kantor pertanahan di Kabupaten/Kota yang berada di Provinsi Jambi.

Provinsi Jambi secara geografis terletak antara $0^{0} \quad 45^{\prime}$ sampai $2^{0} 45^{\prime}$ lintang selatan dan antara $101^{0} 10^{\prime}$ sampai $104^{0} 55^{\prime}$ bujur timur. Sebelah utara berbatasan dengan Provinsi Riau dan Kepulauan Riau, sebelah Timur dengan Laut Cina Selatan, sebelah selatan berbatasan dengan Provinsi Sumatera Selatan dan sebelah Barat berbatasan dengan Provinsi Smatera Barat dan Bengkulu. Luas wilayah Provinsi Jambi $53.435 \mathrm{Km}^{2}$ dengan luas daratan $50.160,05 \mathrm{Km}^{2}$ dan luas perairan sebesar 3.274,95 $\mathrm{Km}^{2}$. BPS Provinsi Jambi (2016)

Provinsi Jambi terdiri dari 2 Kota dan 9 Kabupaten yaitu: Kota Jambi, Kota Sungai Penuh, Kabupaten Kerinci, Kabupaten Merangin, Kabupaten Sarolangun, Kabupaten Batanghari, Kabupaten Muaro Jambi, Kabupaten Tanjung Jabung Timut, Kabupaten Tanjung Jabung Barat, Kabupaten Tebo, dan Kabupaten Bungo.

Berdasarkan uraian diatas, perumusan masalah pada karya tulis ini adalah:

1. Bagaimana jenis sengketa pertanahan yang diselesaikan melalui jalur mediasi di Kantor wilayah Badan Pertanahan Nasional Provinsi Jambi?

2. Bagaimana peran Kantor wilayah Badan Pertanahan Nasional Provinsi Jambi dalam penyelesaian sengketa pertanahan melalui mekanisme mediasi?

Adapun tujuan penulisan ini adalah untuk memetakan jenis sengketa pertanahan yang ada di Provinsi Jambi dan memahami serta mengerti tentang peran Kantor wilayah Badan Pertanahan Nasional Provinsi Jambi dalam penyelesaian sengketa pertanahan melalui mekanisme mediasi.

\section{METODE PENELITIAN}

\section{Lokasi dan Desain Penelitian}

Penelitian ini dilaksanakan di Kantor Wilayah Badan Pertanahan Provinsi Jambi, tipe penelitian ini yang digunakan adalah deskriptif kualitatif yang bertujuan untuk memberikan gambaran secara mendalam tentang peran dan strategi dalam melaksanakan mediasi terhadap sengketa atau konflik pertanahan khususnya konflik pertanahan di Provinsi Jambi. Mediasi yang dimaksud dalam tulisan ini adalah sebagaimana disebutkan pada Pasal 1 angka 7 Permen ATR/BPN No. 11/2016, mediasi adalah cara penyelesaian sengketa dan konflik melalui proses perundingan untuk memperoleh kesepakatan para pihak dengan dibantu oleh mediator.

\section{Objek Penelitian}

Objek penelitian ini adalah pimpinan dan staff Kantor Wilayah Badan Pertanahan Nasional Provinsi Jambi, terutama bagian atau bidang atau seksi yang 
secara khusus memiliki tugas dan kewenangan dalam proses penyelesaian konflik pertanahan. Selain itu, dalam penelitian ini juga melibatkan pihak-pihak yang berkonflik sebagai objek penelitian. Teknik penentuan informan dalam penelitian ini adalah dengan menggunakan teknik purposive sampling yaitu berdasarkan pertimbangan yang erat kaitannya dengan tujuan penelitian.

\section{Metode Pengumpulan Data}

Teknik pengumpulan data yang dilakukan melalui wawancara mendalam dan studi kepustakaan.

\section{Teknik Analisis Data}

Selama peneliti melakukan pengumpulan data di lapangan, peneliti juga melakukan analisis data. Semua data yang telah didapat kemudian diolah melalui tiga jaluar analisis data kualitatif yaitu reduksi data, penyajian data dan penarikan kesimpulan.

\section{PEMBAHASAN}

Jenis sengketa pertanahan yang diselesaikan melalui jalur mediasi di Kantor wilayah Badan Pertanahan Nasional Provinsi Jambi.

Penanganan masalah pertanahan perlu dilakukan secara sederhana, sistematis, terpadu, menyeluruh, terukur, obyektif dan tuntas dalam rangka menetapkan atau memutuskan langkah-langkah penyelesaiannya. Karakteristik dari masalah pertanahan yang muncul merupakan persoalan tersendiri dalam upaya mencari penyelesaiannya. Musyarofah (2011:54).

Sebelum keluarnya Permen ATR/BPN No. 11/2016 pada tanggal 21 Maret 2016, yang menjadi pedoman Badan Pertanahan Nasional dalam menangani sengketa, konflik dan perkara pertanahan adalah Keputusan Badan Pertanahan Nasional Republik Indoesia Nomor 34 Tahun 2007 tentang Petunjuk Teknis Penanganan dan Penyelesaian Masalah Pertanahan.

Penyelesaian sengketa dan konflik oleh BPN dilakukan berdasarkan:

1. Inisiatif dari BPN, dimana Kementrian melalui Kepala Kantor Pertanahan, Kepala Kantor Wilayah BPN atau Direktorat Jendral melaksanaan pemantauan untuk mengetahui Sengketa dan Konflik yang terjadi dalam suatu wilayah tertentu terhadap pengaduan atau pemberitaan pada surat kabar. Selanjutnya, Kakantah melaporkan hasil pemantauan kepada Kakanwil BPN setiap 4 (empat) bulan sekali dan ditembuskan kepada Menteri. Apabila hasil pemantauan perlu ditindaklanjuti, Menteri atau Kakanwil BPN memerintahkan Kakantah untuk melakukan kegiatan penyelesaian Sengketa dan Konflik.

2. Pengaduan dari masyarakat.

Pengaduan disampaikan kepada Kakantah secara tertulis melalui loket pengaduan, kotak surat atau website Kementerian. Apabila pengaduan disampaikan kepada Kakanwil BPN dan/atau Kementerian, selanjutnya berkas pengaduan diteruskan kepada Kakantah.

Setelah petugas menerima pengaduan, selanjutnya petugas akan melakukan pengumpulan data dan analisis terhadap data tersebut. Analisis dilakukan untuk 
mengetahui apakah pengaduan tersebut merupakan kewenangan BPN atau bukan kewenangan BPN. Pasal 11 ayat (3) Permen ATR/BPN No. 11/2016 mengatur tentang sengketa atau konflik yang menjadi kewenangan Kementrian ATR/BPN meliputi:

1. Kesalahan prosedur dalam proses pengukuran, pemetaan dan/atau perhitungan luas;

2. Kesalahan prosedur dalam proses pendaftaran penegasan dan/atau pengakuan hak atas tanah bekas milik adat;

3. Kesalahan prosedur dalam proses penetapan dan/atau pendaftaran hak tanah;

4. Kesalahan prosedurdaam proses penetapan tanah terlantar;

5. Tumpang tindih hak atau sertifikat hak atas tanah yang salah satu alas haknya jelas terdapat kesalahan;

6. Kesalahan prosedur dalam proses pemeliharaan data pendaftaran tanah;

7. Kesalahan prosedur dalam proses penerbitan sertifikat pengganti;

8. Kesalahan dalam memberikan informasi data pertanahan;

9. Kesalahan prosedur dalam proses pemberian izin;

10. Penyalahgunaan pemanfaatan ruang; atau

11. Kesalahan lain dalam penerapan peraturan perundang-undangan.

Sengketa atau konflik selain sebagaimana disebut diatas bukan merupakan kewenangan kementrian dan menjadi kewenangan instansi lain. Dan BPN akan menyampaikan penjelasan secara tertulis kepda pihak pengadu. Tetapi BPN dapat mengambil inisiatif untuk memfasilitasi penyelesaian sengketa atau konflik melalui mediasi.

Sedangkan tipologi kasus pertanahan yang merupakan jenis sengketa, konflik dan atau perkara pertanahan yang disamaikan atau diadukan dan ditangani oleh BPN secara garis besar dikelompokkan menjadi:

1. Penguasaan tanah tanpa hak, yaitu perbedaan persepsi, nilai atau pendapat, kepentingan mengenai status penguasaan di atas tanah tertentu yang tidak atau belum dilekati hak (tanah negara), maupun yang telah dilekati hak oleh pihak tertentu;

2. Sengketa batas, yaitu perbedaan pendapat, nilai kepentingan mengenai letak, batas dan luas bidang tanah yang diakui satu pihak yang telah ditetapkan oleh Badan Pertanahan Nasional Republik Indonesia maupun yang masih dalam proses penetapan batas.

3. Sengketa waris, yaitu perbedaan persepsi, nilai atau pendapat, kepentingan mengenai status penguasaan di atas tanah tertentu yang berasal dari warisan

4. Jual berkali-kali, yaitu perbedaan persepsi, nilai atau pendapat, kepentingan mengenai status penguasaan di atas tanah tertentu yang diperoleh dari jual beli kepada lebih dari 1 orang

5. Sertipikat ganda, yaitu perbedaan persepsi, nilai atau pendapat, kepentingan mengenai suatu bidang tanah tertentu yang memiliki sertipikat hak atas tanah lebih dari 1.

6. Sertipikat pengganti, yaitu perbedaan persepsi, nilai atau pendapat, kepentingan mengenai suatu bidangtanah tertentu yang telah diterbitkan sertipikat hak atas tanah pengganti. 
7. Akta Jual Beli Palsu, yaitu perbedaan persepsi, nilai atau pendapat, kepentingan mengenai suatu bidang tanah tertentu karena adanya Akta Jual Beli palsu.

8. Kekeliruan penunjukan batas, yaitu perbedaan pendapat, nilai kepentingan mengenai letak, batas dan luas bidang tanah yang diakui satu pihak yang teiah ditetapkan oleh Badan Pertanahan Nasional Republik Indonesia berdasarkan penunjukan batas yang salah.

9. Tumpang tindih, yaitu perbedaan pendapat, nilai kepentingan mengenai letak, batas dan luas bidang tanah yang diakui satu pihak tertentu karena terdapatnya tumpang tindih batas kepemilikan tanahnya.

10. Putusan Pengadilan, yaitu perbedaan persepsi, nilai atau pendapat, kepentingan mengenai putusan badan peradilan yang berkaitan dengan subyek atau obyek hak atas tanah atau mengenai prosedur penerbitan hak atas tanah tertentu.(www.bpn.go.id)

Sebagai sebuah program prioritas, penyelesaian kasus-kasus pertanahan senantiasa menjadi perhatian seluruh jajaran BPN RI ditingkat pusat, Kantor Wilayah Provinsi maupun Kantor Pertanahan Kabupaten/Kota seluruh Indonesia. Konsentrasi terbesar dari konflik agraria berdasarkan wawancara yang dilakukan oleh kompas.com adalah sektor perkebunan sebanyak 127 konflik, dan posisi kedua ditempati sektor infrastruktur dengan 70 konflik.

Berikut ini beberapa jenis sengketa yang proses penyelesaiannya melalui Kantor Wilayah Badan Pertanahan Nasional Provinsi Jambi diluar perkara yang diselesaikan melalui pengadilan adalah sebagai berikut:

\begin{tabular}{lcccc} 
Tabel 1 \\
Tipologi Sengketa Konflik di Kanwil BPN Provinsi Jambi \\
\hline TIPOLOGI & $\mathbf{5}$ TAHUN \\
\hline SENGKETA/KONFLIK & $\mathbf{2 0 1 3}$ & $\mathbf{2 0 1 4}$ & $\mathbf{2 0 1 5}$ & $\mathbf{2 0 1 6}$ \\
\hline Kepemilikan bidang tanah & 1 & 3 & 2 & 0 \\
Tumpang tindih kepemilikan tanah & 2 & 0 & 2 & 1 \\
Batas bidang tanah & 0 & 0 & 1 & 1 \\
Pengakuan kepemilikan & 0 & 0 & 1 & 1 \\
Penguasaan dan pemilikan tanah & 0 & 0 & 6 & 1 \\
$\quad$ TOTAL & $\mathbf{3}$ & $\mathbf{3}$ & $\mathbf{1 2}$ & $\mathbf{4}$ \\
\hline
\end{tabular}

Sumber : Bidang PPSKP Kanwil BPN Provinsi Jambi

Hasil dari data penelitian tersebut diatas, yang menjadi penyebab timbulnya sengketa dan konflik pertanahan dari tahun 2014 sampai degan tahun 2016 ternyata yang dominan adalah kepemilikan bidang tanah sebanyak 6 (enam) kasus, tumpang tindih kepemilikan tanah sebanyak 5 (lima) kasus, batas bidang tanah sebanyak 1 (satu) kasus, pengakuan kepemilikan tanah sebanyak 1 (satu) kasus, dan sengketa penguasaan dan pemelikan tanah sebanyak 7 (tujuh) kasus.

Alasan kenapa para pihak memilih mediasi di Kanwil BPN Provinsi Jambi dari pada di kantor pertanahan nasional kabupaten/kota dimana letak tanah tersebut berada berdasarkan penelitian adalah sebagai berikut: 
1. Tidak terselesaikannya proses mediasi yang dilakukan oleh kantor pertanahan nasional kabupaten/kota sehingga para pihak tidak puas dan melanjutkannya ke Kanwil BPN Provinsi sebagai atasan langsung kantor pertanahan nasional kabupaten/kota;

2. Alasan efisiensi, dimana para pihak biasanya bertempat tinggal di Kota Jambi sedangkan lokasi tanah jauh dari kota.

3. Letak tanah yang disengketakan berada di dua kabupaten/kota yang berbeda sehingga salah satu dari kantor pertanahan nasional kabupaten/kota dimana tanah itu berada menyatakan tidak berwenang sehingga dilimahkan ke Kanwil BPN Provinsi.

4. Para pihak merasa sengketa ini terjadi karena kesalahan kantor pertanahan nasional kabupaten/kota sehingga mereka berpendapat untuk membatalkan putusan Pejabat Tata Usaha Negara terseut harus dilakukan oleh lembaga yang lebih tinggi atau diatasnya.

5. Para pihak tidak puas terhadap hasil mediasi yang dilakukan oleh Kantor Pertanahan Kabupaten/Kota sehingga para pihak melanjutkan ke jenjang lebih tinggi dengan harapan akan menemukan solusi yang berkeadilan.

\section{Peran Kantor wilayah Badan Pertanahan Nasional Provinsi Jambi dalam penyelesaian sengketa pertanahan melalui mekanisme mediasi}

Badan pertanahan Nasional (BPN) merupakan lembaga pemerintahan yang bertugas untuk melaksanakan dan mengembangkan administrasi pertanahan. Dalam melaksanakan tugas tersebut, penyelesaian masalah pertanahan merupakan salah satu fungsi yang menjadi kewenangan BPN.

Penyelesaian sengketa tanah melalui mediasi oleh BPN perlu dilandasi dengan kewenangan-kewenangan yang sah berdasarkan peraturan perundang-undangan. Hal ini penting sebagai landasan BPN untuk melakukan mediasi didalam penyelesaian sengketa pertanahan, karena pertanahan dikuasai oleh aspek hukum publik dan aspek hukum privat maka tidak semua sengketa pertanahan dapat diselesaikan melalui mediasi, hanya sengketa pertanahan yang dalam kewenangan sepenuhnya dari pemegang hak saja yang dapat diselesaikan melalui mediasi. Oleh karena itu kesepakatan dalam rangka penyelesaian sengketa melalui mediasi dilakukan pembatasan-pembatasan. Hal ini dimaksudkan agar putusan mediasi tersebut tidak melanggar hukum serta dapat dilakukan secara efektif dilapangan.

Penyelesaian sengketa tanah mencakup baik penanganan masalah pertanahan oleh BPN sendiri maupun penanganan tindak lanjut penyelesaian masalah oleh lembaga lain. Berkaitan dengan masalah pertanahan yang diajukan, BPN mempunyai kewenangan atas prakasanya sendiri untuk menyelesaikan permasalahan yang dimaksud. Dasar hukum kewenangan BPN sebagaimana telah dikemukakan secara eksplisit, tercantum dalam Permen ATR/BPN No. 11/2016.

Penanganan masalah pertanahan melalui mediasi oleh BPN bisanya didasarkan dua prinsip utama, yaitu:

1. Kebenaran-kebenaran formal dari fakta-fakta yang mendasari permasalahan yang bersangkutan; 
2. Keinginan yang bebas dari para pihak yang bersengketa terhada objek yang disengketakan.

Untuk mengetahui kasus posisinya tersebut perlu dilakukan penelitian dan pengkajian secara yuridis, fisik maupun administasi. Putusan penyelesaian sengketa atau masalah tanah merupakan hasil pengujian dari kebenaran fakta objek yang disengketakan. Outputnya adalah suatu rumusan penyelesaian masalah berdasarkan aspek benar atau salah.

Dalam rangka penyelesaian masalah sengketa tersebut untuk memberikan perlakuan yang seimbang kepada para pihak diberikan kesempatan secara transparan untuk mengajukan pendapatnya mengenai permasalahan tersebut. Di samping itu, dalam kasus-kasus tertentu kepada mereka dapat diberikan kebebasan untuk menentukan sendiri rumusan penyelesaian masalahnya. Dalam hal ini BPN hanya menindaklanjuti pelaksanaan putusan secara administratif sebagai rumusan penyelesaian masalah yang telah mereka sepakati.

Penyelesaian sengketa pertanahan termasuk melalui mediasi oleh Badan Pertanahan Nasional perlu dilandasi dengan kewenangan-kewenangan yang sah berdasarkan peraturan perundang-undangan. Hal ini penting sebagai landasan BPN untuk melakukan mediasi di dalam penyelesaian sengketa pertanahan, oleh karena pertanahan dikuasai aspek hukum publik dan hukum privat, tidak semua sengketa pertanahan dapat diselesaikan melalui mediasi.

Penyelesaian sengketa atau konflik salah satu caranya dapat dilakukan melalui mediasi yang berdasarkan prinsip musyawarah untuk mufakat bagi kebaikan semua pihak. Dan menurut ketentuan Pasal 38 ayat (2) Permen ATR/BPN No. 11/2016, mediasi dilakukan paling lama 30 (tiga puluh) hari. Dan berdasarkan ayat (3), mediasi bertujuan untuk:

1. Menjamin transparansi dan ketajaman analisis;

2. Pengambilan putusan yang bersifat kolektif dan obyektif;

3. Meminimalisir gugatan atas hasil penyelesaian sengket dan konflik;

4. Menampung informasi/pendapat dari semua pihak yang berselisih, dan dari unsur lain yang perlu dipertimbangkan; dan

5. Memfasilitasi penyelesaian sengketa dan konflik melalui musyawarah.

Untuk mengetahui kasus posisinya maka Kanwil BPN Provinsi Jambi melakukan penelitian dan pengkajian secara yuridis, fisik maupun administrasi. Setelah melakukan pengkajian maka akan muncul gambaran yang jelas terhadap sengketa pertanahan tersebut dan memunculkan rumusan masalah berdasarkan aspek benar atau salah yang akan diuji pada mediasi yang akan dihadiri oleh para pihak.

Pendekatan yang diutamakan oleh Kanwil BPN Provinsi Jambi dalam menyelesaikan sengketa adalah pendekatan persuasif dengan mengedepankan pendekatan penyelesaian kekeluargaan diantara para pihak yang bertikai. Strategi yang digunakan adalah dengan mengundang pihak-pihak yang bertikai secara terpisah dan mendengarkan pokok permasalahannya, kemudian menganalisis hasil pertemuan tersebut dalam gelar kasus dengan mengundang pejabat dilingkup Kanwil BPN Provinsi Jambi. Gelar kasus tersebut akan menghasilkan langkah-langkah untuk mempercepat proses penyelesaiannya. 
Mengundang para pihak dalam satu forum dilakukan setelah Kanwil BPN mempunyai gambaran yang jelas tentang kasus posisi dari sengketa pertanahan tersebut. Permasalahan yang sering timbul adalah salah satu pihak tidak memenuhi undangan tersebut sehingga dilakukan lagi penjadwalan mediasi. Apabila sampai dengan tiga kali pemanggilan, salah satu pihak tidak juga memenuhi undangan maka mediasi dianggap gagal.

Pasal 39 ayat (1) Permen ATR/BPN No. 11/2016 mengatur tentang peserta mediasi yaitu:

1. Tim Pengelola;

2. Pejabat Kementrian, Kantor Wilayah BPN dan/atau Kantor Pertanahan;

3. Mediator dari Kementrian, Kantor Wilayah BPN dan/atau Kantor Pertanahan;

4. Para pihak dan/atau pihak lain yang terkait; dan/atau

5. Pakar dan/atau ahli yang terkait dengan sengketa dan konflik, Instansi terkait, dan unsur masyarakat, tokoh masyarakat/adat/agama, atau pemerhati/pegiat agraria dan penata ruang, serta unsur-unsur lain, apabila diperlukan.

Dalam menyelesaiakan segala konflik yang ada, Kanwil BPN Provisi Jambi mengambil jalan mediasi yaitu dengan mempertemukan kedua pihak yang terlibat dalam konflik dan membicarakannya dengan jalan kekeluargaan. Hal ini sesuai dengan pendapat Abdurrahman (2009) bahwa Pola-pola penyelesaian konflik pertanahan di luar pengadilan yang dilakukan adalah negosiasi, musyawarah mufakat dan mediasi. Negosiasi dilakukan dengan jalan dimana para pihak yang berkonflik duduk bersama untuk mencari jalan terbaik dalam penyelesaian konflik dengan prinsip bahwa penyelesaian itu tidak ada pihak yang dirugikan (win-win solution), kedua pihak tidak ada yang merasa dirugikan. Musyawarah mufakat adalah lengkah lebih lanjut dari negosiasi. Jika dalam negosiasi tidak terdapat kesepakatan yang saling menguntungkan, maka langkah lebih lanjut adalah melakukan musyawarah mufakat dengan melibatkan pihak lain selaku penengah. Hasil musyawarah tersebut selanjutnya dibuatkan surat kesepakatan bersama yang ditanda tangani oleh para pihak dan para saksi.

Peran Kanwil BPN Provinsi Jambi dalam memfasilitasi mediasi, dilakukan dengan mempertemukan kedua belah pihak yang terlibat dalam sengketa tanah beserta pihak dari Kantor Pertanahan Kabupaten/Kota dimana lokasi tanah sengketa tersebut berada. Hal ini sesuai dengan pendapat Mudjiono (2007), bahwa Mediasi merupakan pengendalian konflik pertanahan yang dilakukan dengan cara membuat konsensus diantara dua pihak yang berkonflik untuk mencari pihak ketiga yang berkedudukan netral sebagai mediator dalam penyelesaian konflik.

Didalam Permen ATR/BPN No. 11/2016 disbutkan bahwa peran BPN seharusnya sebagai mediator dalam menyelesaikan sengketa atau konflik. Tetapi Kanwil BPN Provinsi Jambi menganggap bahwa peran Kanwil BPN Provinsi Jambi hanya sebagai fasilitator saja, bukan sebagai mediator. Hal ini terkait perbedaan persepsi definisi dari mediator. Menurut Pasal 1 angka (8) mediator adalah pihak yang membantu para pihak dalam proses perundingan guna mencari berbagai kemungkinan penyelesaian sengketa atau konflik tanpa menggunakan cara memutus atau memaksakan sebuah penyelesaian. Sedangkan definisi mediator menuru Kanwil BPN Provinsi Jambi adalah orang atau pihak yang harus mempunyai sertifikat 
mediator dan membantu proses mediasi. Tetapi perbedaan definisi tersebut tidak mempengaruhi proses mediasi di Kanwil BPN Provinsi Jambi

Penyelesaian secara mediasi baik yang bersifat tradisional ataupun melalui berbagai Lembaga Alternative Dispute Resolution (ADR) mempunyai kelebihan bila dibandingkan dengan berperkara di muka pengadilan yang tidak menarik dilihat dari segi waktu, biaya dan pikiran/tenaga. Disamping itu kurangnya kepercayaan atas kemandirian lembaga peradilan dan kendala administrasi yang meliputinya membuat pengadilan merupakan pilihan terakhir untuk penyelesaian sengketa.

Output yang diharapkan dari mediasi yang dilakukan oleh Kantor Wilayah BPN Provinsi Jambi adalah para pihak bisa memahami letak permasalahan sengketa tersebut secara utuh dan yang terutama dari hasil mediasi adalah adanya perdamaian dari para pihak. Apabila para pihak tidak mencapai kata sepakat, maka bisa dilanjutkan ke ranah litigasi atau melalui lembaga peradilan.

\section{KESIMPULAN}

Dari paparan dan uraian diatas, dapat disimpulkan bahwa:

1. Tipologi sengketa atau konflik pertanahan yang diselesaikan melalui jalur mediasi di Kantor wilayah Badan Pertanahan Nasional Provinsi Jambi terdiri dari sengketa penguasaan dan kepemilikan tanah, sengketa batas, tumpang tindih batas dan sengketa kepemilikan.

2. Peran Kantor wilayah Badan Pertanahan Nasional Provinsi Jambi dalam penyelesaian sengketa pertanahan melalui mekanisme mediasi sudah sesuai peraturan perundang-undangan yang ada walaupun terjadi perbedaan antara definisi mediator yang dimaksud Permen ATR/BPN No. 11/2016 dengan yang terjadi dilapangan.

Adapun saran yang dapat diberikan kepada Kanwil BPN Provinsi Jambi dan para pihak dalam mediasi adalah:

1. Melakukan penyuluhan dan sosialisasi mediasi sebagai langkah awal dalam menyelesaikan sengketa pertanahan dikarenakan dalam mediasi permasalahan bisa diketahui secara menyeluruh dan tuntas.

2. Meningkatkan kemampuan para mediator di pihak Kanwil BPN Provinsi Jambi sehingga mediasi menjadi lebih efektif, cepat dan terarah.

3. Membuat dasar hukum yang berimplikasi terhadap pihak yang tidak hadir walaupun diundang secara layak dalam proses mediasi sehingga tidak ada pembiaran yang disengaja terhadap proses mediasi.

\section{DAFTAR PUSTAKA}

Abdurrahman, 2009, Penyelesaian Sengketa Pertanahan. Jakarta: Mahkamah Agung Republik Indonesia.

http://properti.kompas.com/read/2016/01/05/200000121/Konflik.Agraria.Terbanyak.

Terjadi.di.Sektor.Perkebunan.dan.Infrastruktur

http://www.bpn.go.id/Layanan-Publik/Program/Penanganan-Kasus-Pertanahan\#

diakses pada tanggal 25 April 2017.

Mudjiono, 2007, Alternatif Penyelesaia Sengketa Pertanahan di Indonesia Melalui

Revitalisasi Fungsi Badan Peradilan, Yogyakarta: Jural Hukum Vol. 14 No.3. 
Musyarofah, 2011, Mediasi dalam Sengketa Pertanahan di Kantor Pertanahan Kabupaten Pati, Semarang: Fakultas Ilmu Sosial Universitas Negeri Semarang. Rachmadi Usman, 2003, Pilihan Penyelesaian Sengketa di Luar Pengadilan, Bandung: PT. Citra Aditya Bakti.

Rusmadi Murad, 1991, Penyelesaian Sengketa Hukum Atas Tanah, Bandung: Mandar Maju. 